\title{
Attitudes and Willingness to Pay More for Organic Foods by Tennessee Consumers
}

\author{
Hiren Bhavsar ${ }^{1}$, Fisseha Tegegne ${ }^{1}$, Kofi Baryeh ${ }^{1} \&$ Prabodh Illukpitiya $^{1}$ \\ ${ }^{1}$ Department of Ag \& Environmental Sciences, Tennessee State University, Nashville, Tennessee, USA \\ Correspondence: Hiren Bhavsar, Department of Ag \& Environmental Sciences, Tennessee State University, \\ Nashville, Tennessee, USA. Tel: 1-615-963-1498. E-mail: hbhavsar@tnstate.edu
}

Received: September 25, 2017

Accepted: March 2, 2018 Online Published: May 15, 2018

doi:10.5539/jas.v10n6p33

URL: https://doi.org/10.5539/jas.v10n6p33

\begin{abstract}
This paper examines the general knowledge of consumers regarding organic food and determines their willingness to pay more for it. Data was collected using a random sample of grocery shoppers in the state of Tennessee. The study reveals most of the respondents had a fair knowledge of what organic food was. The number of respondents who had never purchased organic food was found to be only slightly higher than the number who purchase it. A binary logistic regression found income and Environmental concern to be factors that effectively determine willingness to pay more for organic food.
\end{abstract}

Keywords: organic food, willingness to pay, Tennessee consumers

\section{Introduction}

United States (US) consumer demand for organically produced goods has grown continuously since the United States Department of Agriculture (USDA) established national standards for organic production and processing in 2002 (Green, 2013). Organic food sales have also increased from approximately $\$ 11$ billion in 2004 to an estimated \$27 billion in 2012 (USDA, 2012). Organic sales accounted for more than 3.5 percent of total U.S. food sales in 2012 (USDA, 2012).

According to new Economic Research Service (ERS) estimates, the U.S. had 3.1 million acres of certified organic cropland in 2011 and 2.3 million acres of certified organic pasture and rangeland, continuing the long-term growth trend in the sector (Green, 2013). The growth in organic agriculture is being experienced globally. This has increased the competition among producers and retailers for consumers. U.S. producers and retailers have been challenged to increase their output as well as the variety of organic food offering in an effort to meet rising demand. There has been significant attention paid to the industry due to diseases caused by the consumption of food with pesticide residue (Andreia \& Eloisa, 2012). Consumers are also increasingly more conscious about their health since the health effects of the use of pesticides and fertilizers in conventional food production has been established to be detrimental.

\subsection{Food Safety}

Food consumption patterns are rapidly changing as a result of consumers' concern about the nutritional value of food as well as their health. Environmental and health concerns seem to be very strong motives for consumers when purchasing organic food (Tsakiridou et al., 2008). The concern for the choice of food consumers purchase and consume has been made prominent partly due to some recent food scares as well as the claim that organically grown food is healthier than conventionally grown food. Conventional food production is characterized by the use of heavy doses of synthetic pesticides and fertilizers which often leave residues in the edible portion of the crop. Consumers see organic food products to be healthier than non-organic food products because of the low levels of pesticide and medicine residues (Saba \& Messina, 2003; Wier et al., 2008). They also view it as a safer option since they believe consuming it reduces their chances of being exposed to illnesses associated with pesticide residues. According to the literature, these health concerns are addressed by organic farming and the use of safer food processing methods (Furnham, 2007; Petrie et al., 2001).

\subsection{The U.S. Organic Food Industry and Willingness to Pay}

Organic production in various sectors of the U.S. agricultural industry has seen tremendous increase. Certified organic farmland doubled between 2002 and 2005. Growing at a rate of between $12 \%$ and $21 \%$ percent annually, 
organic food accounts for $3 \%$ of the total U.S. food sales and is expected to grow at a similar rate for the next few years (USDA, 2009). The United States is the leading producer and consumer of organic food followed by European countries and Japan (Helga \& Kilcher, 2009). Despite the fact that the organic market share and growth rate differ substantially across countries (Organic Monitor, 2010; Thøgersen, 2010), it is obvious that organic food is rapidly becoming an important sub-sector in the food industry. Simultaneously the organic food chain has been transformed from a local network of producers and consumers to a highly coordinated and formally regulated supply system (Raynolds, 2004).

The organic food market in the U.S. and some European countries such as France and the United Kingdom is characterized by particularly low market shares, although Switzerland, Denmark, and Austria report better shares (Biomonitor, 2009). Thus, there is need to understand why these market shares are low. Most of the literature attributes this to the fact that organic foods are generally more expensive compared to non-organic food. ACNielsen (2005) reported that higher cost was perceived as the main barrier to organic food consumption for one third of respondents in the Asia Pacific region and over 40\% of European and North American consumers.

A number of studies such as Owusu and Anifori (2013), Dipeolu (2009), Maguire et al. (2004), Govindasamy et al. (2006), Govindasamy and Italia (1999), Obayelu (2014), Aguilar and Vlosky (2007), De Pelsmacker et al. (2005), Saphores et al. (2007), all found consumers to be willing to pay (WTP) more for organic food to some degree.

However a small number of studies have reported WTP premiums closer to zero and in some cases to be negative. A study by $\mathrm{Hu}$ et al. (2009) found consumer preference and willingness to pay strongest for products identified as local, as opposed to products identified as organic. Loureiro and Hine (2002) also came to a similar conclusion when they detected willingness to pay a higher premium for Colorado grown than for potatoes identified as organic. Krystallis and Chryssohoidis (2005) are of the view that consumption of organic food has not caught on with the general public due to the relatively higher prices, lack of availability, lack of awareness of the organic concept and uncertainty over the truthfulness of organic food claims. Pacnoski (2009) also stresses organic farming may satisfy more affluent consumers, but extending it to the poverty stricken communities would be disastrous since such areas are characterized by low income per capita. He implies those with higher levels of disposable income will be more willing to pay for organic food than those with lower levels of disposable income.

\section{Methodology and Data}

A structured questionnaire was administered to a random sample of 81 grocery shoppers through the Survey Monkey platform. The survey was divided into four sections. The first section consisted of questions on consumer awareness of organic food and factors that determine their food purchasing behavior. After the first section respondents who indicated they purchased organic food were skipped to the third section while those who indicated they did not, moved to the second section. This section was aimed at finding out why non purchasers chose not to purchase organic food. The third section consisted of questions on respondents' organic food purchasing behavior. The last section was related to the respondents' demographic profile.

The study employed descriptive analysis to assess the knowledge of consumers regarding organic food and employed the binary logistic regression to determine factors that influence consumer's willingness to pay more for organic food.

The empirical model of the effect of a set of explanatory variables on organic food purchase behavior is specified using the following linear relationship:

$$
Y=\beta_{0}+\beta_{1} \text { income }+\beta_{2} \text { env }+\beta_{3} \text { food safety }+\varepsilon_{1}
$$

With $Y$ taking on values of (1) where the respondent is willing to pay more for organic food and (0) where respondent indicates otherwise. 
Table 1. Description of independent variables used in the logistic regression model.

\begin{tabular}{lll}
\hline Parameter & Label & Unit of Measurement \\
\hline Income (Categorical) & Inc & $1-<\$ 29,999$ \\
& & $2-\$ 30,000-\$ 74,999$ \\
& & $3->\$ 75,000$ \\
\hline Environmental Concerns (Dummy variable) & Env & $1-$ Important \\
& & 0 - Unimportant \\
Food safety Concerns (Dummy variable) & FoodSafety & 1 - Important \\
& & 0 - Unimportant \\
\hline
\end{tabular}

Table 1 shows a description of the independent variables used in the model. Income was split in three categories to classify the poor, middle class and higher class. Environmental concerns and food safety concerns were binary variables as they were asked as a 'yes' or 'no' questions in the questionnaire.

\section{Results and Discussion}

\subsection{Demographics}

Approximately $55 \%$ of the total respondents were females while approximately $44 \%$ were males. The 2013 population estimate of the state of Tennessee show females constituted $51.2 \%$ of the population (US Department of Commerce 2015).

The household income of respondents were almost evenly distributed among the $\$ 50,000-\$ 75,000$, $\$ 76,000-\$ 100,000$ and above $\$ 100,000$ categories. Each of these categories had approximately $22 \%$ of the respondents falling within. Most of the respondents were in highly educated category. Approximately $80 \%$ had either attempted college, completed college and/or completed a graduate degree. A greater percentage of respondents had a graduate degree.

\subsection{Knowledge of Organic Food}

Most of the respondents claimed they had a fair knowledge of what organic food was. This was expected considering the level of promotion the organic industry enjoys on mainstream media outlets in the U.S. Figure 1 shows a greater number of the respondents claimed they knew something about organic food.

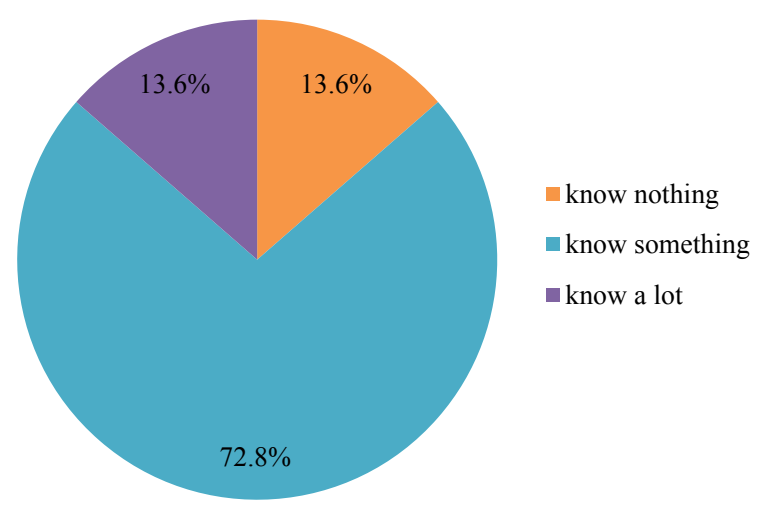

Figure 1. Respondent's knowledge of organic food

A cross tabulation of respondents knowledge of organic food and their purchasing behavior (Table 2) reveal that most of the respondents who claim to know nothing about organic food fall in the category of non-purchasers. This shows that some knowledge of organic food to a large extent affects its purchase and subsequent consumption. 
Table 2. Cross checking purchasing behavior with respect to knowledge of organic food

\begin{tabular}{lll}
\hline & \multicolumn{2}{c}{ Organic food Purchasing Behavior } \\
\cline { 2 - 3 } & Non-purchasers & Purchasers \\
\hline Knew Nothing & $90.9 \%$ & $9.1 \%$ \\
Knew Something & $50.8 \%$ & $49.2 \%$ \\
Knew a lot & $36.4 \%$ & $63.6 \%$ \\
Total & $54.3 \%$ & $45.7 \%$ \\
\hline
\end{tabular}

Respondents were asked whether they were familiar with the USDA organic certification standard (Table 3). Accordingly, most of the respondents indicated they were unfamiliar with the USDA standards. Only $32.10 \%$ claimed they were familiar with the standards. Most of those who claimed indicated that they were familiar with the standards when they purchased organic food. This result is expected since according to Shafie \& Rennie (2012) familiarity with organic food practices influence purchasing behavior. The literature stresses that the more familiar an individual is about organic food practices, the greater the chances of said individual purchasing it.

Table 3. Familiarity with USDA organic certification standards

\begin{tabular}{llll}
\hline & Non-Purchasers & Purchasers & Total \\
\hline Familiar & $11 \%$ & $21 \%$ & $32 \%$ \\
Unfamiliar & $43 \%$ & $25 \%$ & $68 \%$ \\
\hline
\end{tabular}

More than half of the respondents claimed they could recognize the USDA organic food label. However; they were not presented with the label so these claims could not be verified.

\subsection{Willingness to Pay More}

Table 4 shows the results of a binary logistic regression which was conducted with willingness to pay more as the dependent variable. The resulting model has a Nagelkerke $\mathrm{R}^{2}$ statistic of 0.497 , hence satisfactorily explaining approximately $50 \%$ of the variance of the dependent variable. According to the regression results, one of the variables was not significant while the other two variables were significant. This indicates that willingness to pay according to our model is determined by consumers' income and their concerns for the environment. Both income and environmental variables were significant at the $5 \%$ level.

Table 4. Logit Analysis Results for Willingness to pay more for organic food

\begin{tabular}{lllllll}
\hline-2 log Likelihood & 57.590 & & & & \\
Cox \& Snell R Square & .334 & & & & & \\
Nagelkerke R Squared & $\mathbf{. 4 9 7}$ & & & & & \\
\hline & Parameter & Standard Error & Wald Statistic & Degrees of Freedom & p-value & Exp(B) \\
\hline Income & & & 9.162 & 2 & $\mathbf{. 0 1 0} * *$ \\
$<\$ 30,000$ & .279 & .794 & .124 & 1 & .725 & 1.322 \\
$\$ 30,000-\$ 75,000$ & 2.490 & .897 & 7.704 & 1 &. $.006 * *$ & 12.061 \\
Food Safety & -.062 & .810 & .006 & 1 & .939 & .940 \\
Environmental & 3.000 & .827 & 13.145 & 1 & $\mathbf{. 0 0 0} * *$ & 20.082 \\
Constant & -1.036 & .806 & 1.653 & 1 & .199 & .355 \\
\hline
\end{tabular}

Note. ${ }^{* *}$, represents, $5 \%$ level of significance.

Source: Author's Computation.

The income category of ' $<\$ 30,000$ ' was not significant whereas ' $\$ 30,000-\$ 75,000$ ' was significant at the $5 \%$ level. The income category of ' $\$ 30,000.00-\$ 75,000.00$ ' had an odds ratio of 12.06 . This means respondents who fall in the ' $\$ 30,000.00-\$ 75,000.00$ ' income category had odds of being willing to pay more for organic food that are 12.06 the odds of respondents who fall in the $\$ 76,000.00->\$ 100,000.00$ category. In other words they are approximately 12 times more likely to be willing to pay more for organic food. Respondents in the $<\$ 30,000$ category were also more willing to pay more for organic food than respondents in the reference group (though not as much as ' $\$ 30,000-\$ 75,000$ ') even though it was not significant. This result was not expected since 
consumers with higher incomes were expected to be willing to pay more for organic food considering it is more expensive. It can be argued that beyond a certain income level, income ceases to be a major factor in determining the willingness to pay more for some products. The results show household income influence consumers' willingness to pay more for organic food at levels below $\$ 75,000$ however it becomes irrelevant for income above $\$ 75,000.00$ Respondents who indicated they were concerned about the environment had odds of being willing to pay more for organic food that are 20.08 the odds of those who reported "no concern" for environmental issues such as biodiversity, deforestation, pollution etc. This was expected since organic produce and other ingredients are grown without the use of pesticides, synthetic fertilizers, sewage sludge, genetically modified organisms, or ionizing radiation. Organic food production also employs sustainable practices such as mechanical weed control, biological pest control etc.

\subsection{Future Plan of Organic Food Consumption}

The study tried to find out the future plan of organic food purchasers since their continued patronage is very critical to the continued success of the industry. Even though the number of people who consume organic food has been increasing over the past decade it still remains a very minute portion of the total food purchasing population. It is essential that consumers who do not purchase organic food are enticed to start purchasing it. However it is more critical that those who already purchase it either maintain their current consumption or increase it. This creates an opportunity for actors along the value chain of organic products to expand their operations in order to meet this rise in demand. Figure 2 reveals $57 \%$ of purchasers of organic food indicated they are willing to increase their consumption while $43 \%$ indicated they would rather maintain their consumption.

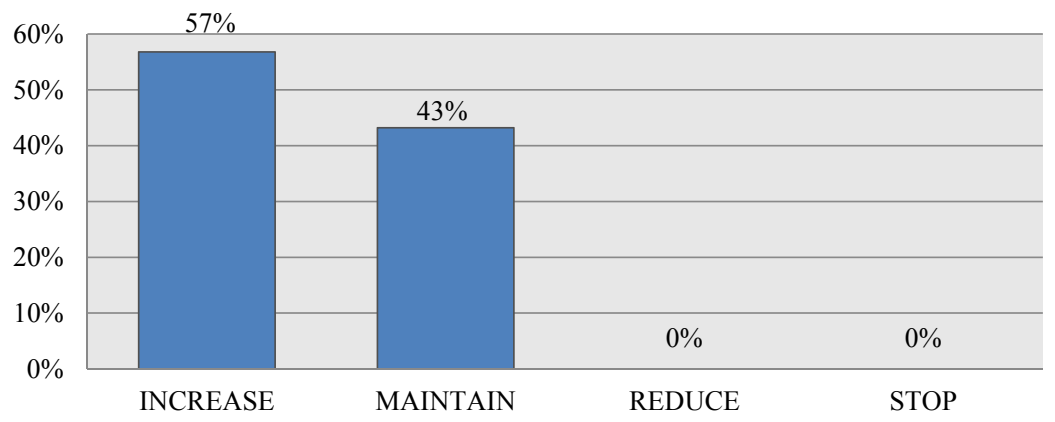

Figure 2. Future plan regarding organic food consumption

\section{Conclusion}

An analysis of consumers knowledge of organic food revealed even though most of the respondents were not familiar with the USDA organic food standards, more than $60 \%$ of them could recognize the USDA organic food label, were familiar with organic food production practice and the makeup of organic food. This is encouraging since the knowledge of a product is critical in making the decision to purchase or not to purchase. Proponents of organic food need to educate the public on the benefits of consuming organic food over non-organic food so as to increase the organic food share in Tennessee.

The study reveals through a binary logistic regression that a higher income is not the sole factor that determines willingness to pay for organic food. Food retailers should find out the other factors that simulate consumers' organic food purchasing behavior so they are able to effectively market their products to the right consumer segment. The logistic regression also revealed consumers who are environmentally conscious are more willing to pay more for organic food. This group of consumers associates organic food with environmental protection and animal welfare. Therefore grocery retailers should encourage consumers in their advertising campaigns to perceive the benefits of buying organic fresh fruits and vegetables by stressing how patronizing it contributes to environment protection and animal welfare rather than concentrating solely on the health benefits aspect. Marketers should emphasize on communicating the environmental benefits related to the production and consumption of organic food.

None of the respondents who purchase organic food gave any indication of either reducing or stopping their consumption. All of them indicated they were willing to either increase or maintain their consumption at current 
level. This scenario is encouraging since it indicates the level of organic food purchase and consumption will not reduce in the future.

Results of this study indicate consumer knowledge regarding organic food affects their purchasing. It also shows Tennessee consumers have a fair knowledge of what constitute organic food. Finally, higher income consumers are more willing to patronize organic food than consumers who have low income.

\section{Limitations}

The study has a limitation of data. Due to lack of resources and low number of observations the number of controllable variables were limited in the logistic regression analysis. This study aims to serve as a base for consumers' preference studies on organic food in Tennessee. The goal of this paper is to provide insight on the organic/conventional food purchasing behaviors among Tennesseans. This study can also serve as a base for other states and regions in the United States or other countries.

\section{References}

ACNielsen. (2005). Organic and functional foods have plenty of room to grow according to new ACNielsen global study. Retrieved from http://usacnielsencom/news

Aguilar, F. X., \& Vlosky, R. P. (2007). Consumer Willingness to Pay Price Premiums for Environmentally Certified Wood Products in the U.S. Forest Policy and Economics, 9, 1100-1112. https://oi.org/10.1016/ j.forpol.2006.12.001

Andreia, N. O., \& Eloisa, D. C. (2012). Brazilian Monitoring Programs for Pesticide Residue in Food-Results from 2001 to 2010. Food Control, 25(2), 607-616. https://doi.org/10.1016/j.foodcont.2011.11.001

Biomonitor. (2009). Biomonitor jaarrapport 2009 [Biomonitor year report]. Breda: Task Force Marktontwikkeling Biologische Landbouw.

De Pelsmacker, P., Driesen, L., \& Rayp, G. (2005). Do Consumers Care About Ethics? Willingness to Pay for Fair-Trade Coffee. Journal of Consumer Affairs, 39(2), 363-386. https://doi.org/10.1111/j.1745-6606. 2005.00019.

Dipeolu, A. O., Philip, B. B., Aiyelaagbe, I. O., Akinbode, S. O., \& Adedokun, T. A. (2009). Consumer awareness and willingness to pay for organic vegetables in S.W. Nigeria. Asian Journal of Food and Agro-Industry, Special Issue, S57-S65.

Furnham, A. A. (2007). Are modern health worries, personality and attitudes to science associated with the use of complementary and alternative medicine? British Journal of Health Psychology, 12(2), 229-243. https://doi.org/10.1348/135910706X100593

Govindasamy, R., \& Italia, J. (1999). Predicting willingness-to-pay a premium for organically grown fresh produce. Journal of Food Distribution Research, 30, 44-53.

Govindasamy, R., De Congelio, M., \& Bhuyan, S. (2006). An Evaluation of Consumer Willingness to Pay for Organic Produce in the Northeastern U.S. Journal of Food Products Marketing, 11(4), 3-20. https://doi.org/10.1300/J038v11n04_02

Green, C. (2013). Organic Production. Economic Research Service, United States Department of Agriculture. Retrieved from http://www.ers.usda.gov/data-products/organic-production.aspx

Helga, W., \& Kilcher, L. (2009). The World of Organic Agriculture. Statistics and Emerging Trends 2009 [FIBL-IFOAM Report]. IFOAM, Bonn; FiBL, Frick; ITC, Geneva.

Hu, W., Woods, T., \& Bastin, S. (2009). Consumer Acceptance and Willingness to Pay for Blueberry Products with Nonconventional Attributes. Journal of Agricultural and Applied Economics, 41(1), 47-60. https://doi.org/10.1017/S1074070800002546

Huber, M., Bakker, M. H., Dijk, W., Prins, H. A., \& Wiegant, F. A. (2012). The challenge of evaluating health effects of organic food: Operationalisation of a dynamic concept of health. Journal of the Science of Food and Agriculture, 92(14), 2766-2773. https://doi.org/10.1002/jsfa.5563

Krystallis, A., \& Chryssohoidis, G. (2005). Consumers' willingness to pay for organic food: Factors that affect it and variation per organic product type. British Food Journal, 107(5), 320-343. https://doi.org/10.1108/ 00070700510596901 
Loureiro, M. L., \& Hine, S. (2002). Discovering Niche Markets: A Comparison of Consumer Willingness to Pay for Local (Colorado Grown), Organic, and GMO-Free Products. Journal of Agricultural and Applied Economics, 34(3), 477-487. https://doi.org/10.1017/S1074070800009251

Maguire, K. B., Owens, N., \& Simon, N. B. (2004). The Price Premium for Organic Babyfood: A Hedonic Analysis. Journal of Agricultural and Resource Economics, 29(1), 132-149.

Obayelu, O. A., Agboyinu, O. M., \& Awotide, B. A. (2014). Consumers' Perception and Willingness to Pay for Organic Leafy Vegetables in Urban Oyo State, Nigeria. European Journal of Nutrition \& Food Safety, 4(2), 128-136. https://doi.org/10.9734/EJNFS/2014/6498

Organic Monitor. (2010). The Global Market for Organic Food \& Drink: Business Opportunities \& Future Outlook. London: Organic Monitor.

Owusu, V., \& Owusu, A. M. (2013). Consumer Willingness to Pay a Premium for Organic Fruit and Vegetable in Ghana. International Food and Agribusiness Management Review, 16(1), 67-86.

Pacnoski, Z. (2009). The myth of organic agriculture. Plant Protection Science, 45(2), 39-48. https://doi.org/ 10.17221/43/2008-PPS

Petrie, K. J., Sivertsen, B., Hysing, M., Broadbent, E., Moss-Morris, R., \& Eriksen, H. R. (2001). Thoroughly modern worries: The relationship of worries about modernity to reported symptoms, health and medical care utilization. Journal of Psychosomatic Research, 51(1), 395-401. https://doi.org/10.1016/S0022-3999 (01)00219-7

Raynolds, L. T. (2004). The Globalization of organic agro-food networks. World Development, 32(5), 725-743. https://doi.org/10.1016/j.worlddev.2003.11.008

Saba, A., \& Messina, F. (2003). Attitudes towards organic foods and risk/benefit perception associated with pesticides. Food Quality and Preference, 14, 637-645. https://doi.org/10.1016/S0950-3293(02)00188-X

Saphores, J. M., Nixon, H., Ogunseitan, O. A., \& Shapiro, A. A. (2007). California Households' Willingness to Pay for 'Green' Electronics. Journal of Environmental Planning and Management, 50, 113-33. https://doi.org/10.1080/09640560601048549

Shafie, F. A., \& Rennie, D. (2012). Consumer Perceptions towards Organic Food. Procedia-Social and Behavioral Sciences, 49, 360-367. https://doi.org/10.1016/j.sbspro.2012.07.034

Thøgersen, J. (2010). Country differences in sustainable consumption: The case of organic food. Journal of Macromarketing, 30(2), 171-185. https://doi.org/10.1177/0276146710361926

Tsakiridou, E., Boutsouki, C., Zotos, Y., \& Mattas, K. (2008). Attitudes and Behaviour towards Organic Products: An Exploratory Study. International Journal of Retail \& Distribution Management, 36(2), 158-175. https://doi.org/10.1108/09590550810853093

US Department of Commerce. (2013). United States Census Bureau-Quick Facts. Retrieved January 3, 2015, from http://quickfacts.census.gov/qfd/states/47000.html

Wier, M., O'Doherty Jensen, K., Mørch Andersen, L., \& Millock, K. (2008). The character of demand in mature organic food markets. Great Britain and Denmark compared. Food Policy, 33(5), 406-421. https://doi.org/ 10.1016/j.foodpol.2008.01.002

\section{Copyrights}

Copyright for this article is retained by the author(s), with first publication rights granted to the journal.

This is an open-access article distributed under the terms and conditions of the Creative Commons Attribution license (http://creativecommons.org/licenses/by/4.0/). 